\title{
Reading the Bible with the marginalised: The value/s of contextual Bible reading
}

\author{
West, Gerald \\ University of KwaZulu-Natal \\ West@ukzn.ac.za
}

\begin{abstract}
There is a long history of collaboration between "popular" or "contextual" forms of biblical interpretation between Brazil and South Africa, going back into the early 1980s. Though there are significant differences between these forms of Bible "reading", there are values and processes that cohere across these contexts, providing an integrity to such forms of Bible reading. This article reflects on the values and processes that may be discerned across the Brazilian and South African interpretive practices after more than thirty years of conversation across these contexts.
\end{abstract}

\section{Keywords}

Popular reading of the Bible, contextual Bible study, See-Judge-Act, Tamar, the labourers in the vineyard

\section{Introduction}

From 25-30 January this year (2015), I participated in a workshop, "Networking 'contextual Bible reading' project: structures of violence", held in Bogotá, Colombia. Among those hosting the workshop were CEBI (Centro de Estudos Bíblicos) (Brazil) and the Ujamaa Centre for Community Development and Research (South Africa). These organisations have a long history, with CEBI having been established in 1979, and the Ujamaa Centre in 1989.

The Ujamaa Centre, the base from which I do much of my biblical studies work, and CEBI have related to each other since the early 1980s. Gunther Wittenberg, a South African biblical scholar standing within the liberation theology tradition, visited CEBI in 1988, and I visited CEBI for the first time in 1990, and there have been many other visits in both directions during 
this time. So central among the factors in the formation of the Ujamaa Centre was the model that CEBI provided.

The purpose of the workshop in Colombia was, as the title suggests, a way of networking those who were doing forms of "contextual Bible reading". There were four layers of participants among the forty participants who came from Colombia, Guatemala, Brazil, Costa Rica, the USA, Scotland, the Netherlands, India, Cameroon, Kenya, and South Africa. The primary layer was those who had been formed by the liberation struggles in Brazil and South Africa (and related contexts) in the 1970s and 1980s, and whose forms of contextual Bible reading or popular reading of the Bible (da Leitura Popular da Bíblia) where shaped by these struggles. The second layer were those who had no direct relationship with the social movements of the 1970s and 1980s, but who had some experience in this liberatory form of contextual Bible reading and who had some connection to organisations or movements of contextual Bible reading. The third layer were individuals, most of them young, who had little experience but who wanted to become practitioners of contextual Bible reading and a part of contextual Bible reading networks, though they might not be clear on the precise commitments and contours of contextual Bible reading as understood within the liberation tradition. And the fourth layer included a range of participants, including some academics who wanted to understand this form of contextual Bible reading and some practitioners engaged in other forms of contextual Bible reading who were concerned to understand the relationships between different forms of contextual Bible reading. Among this last category of participants were those who had extensive experience in the Casitas Bíblicas ("Bible house") movement, Colectivo Ecuménico de Biblistas (CEDEBI), and Intercultural Bible Reading, a recent initiative in contextual Bible reading with links to liberation theology but with different priorities (De Wit 2004, 2012, West 2015b).

This diversity of participation required regular clarification of the forms of "contextual Bible reading" being experienced through this workshop. But as this was a "process" driven workshop, theoretical and methodological clarification were not the first moment of the workshop. The workshop was structured within a See-Judge-Act process (see below). Each of the three components (See-Judge-Act) was itself imbedded in a sharing of our local spiritualties and in corporate spiritual formation together. The "See" 
component began with a recognition and sharing of our different realities. So the first day and a half were devoted to a series of liturgical and groupprocess exercises, enabling participants to get to know each other and to share their contextual realities. The second, third, and fourth day were dedicated to particular experiences of contextual Bible reading, as part of the process of the "Judge" moment within the See-Judge-Act process. The workshop offered three in-depth experiences with three different, yet related, forms of contextual Bible reading. The first was the intercultural form of contextual Bible reading that had been practised in Colombia, including a number of local Colombian participants from this project. The second was a visit to number of the Casitas Bíblicas located on the outskirts of Bogotá. The third was the Contextual Bible Study (CBS) form of contextual Bible reading of the Ujamma Centre from South Africa, and the fourth was da Leitura Popular da Bíblia form of contextual Bible reading practised by $\mathrm{CEBI}$.

In each case workshop participants were given the opportunity to participate in and so experience each of these forms of contextual Bible reading before being offered analysis of the theoretical and methodological scaffolding of each of these forms. The experience of these different forms of contextual Bible reading generated a host of questions among participants, and so the morning of the final day, as the workshop was moving into the "Act" moment, was given over to theoretical and methodological reflection.

In preparation for this conceptual "clearing" and clarification, CEBI and the Ujamaa Centre met to draft a joint presentation, recognising as we have for more than twenty five years that our theoretical and methodological "commitments" were very similar. The next section of this article draws on our presentation, focussing in particular on the work of the Ujamaa Centre.

\section{The core values}

We agreed that it was important to clarify our "political" (to use CEBI's term) or "ideological" (to use Ujamaa's term) values. To put it crudely, we shared certain core values or commitments that we felt were "nonnegotiable". To do contextual Bible reading within our conceptualisation of this practice required a commitment to these core values. 
As we discussed our core values together, we drew on the long conceptual conversation that characterised our work (see for example Mesters 1984, Mesters 1989, nd, West 1991, 1993, 1995, Dreher 2004, Wittenberg 2007, Schinelo 2009, West 2011b, a). Within the literature of CEBI there were five core values, one for each finger of a hand. Within the literature of Ujamaa there were four or five (West 1993, Nadar 2009, 2012) core commitments. This workshop gave us an opportunity, as was intended, both to learn from each other and to consolidate our reflections on our practices. As we talked together we discerned that our various core value categories could be consolidated in the form of five "C" $\mathrm{s}$ ' (for pedagogical purposes): Community, Criticality, Collaboration, Change, and Context. We also agreed, among those present, that there was a sixth " $C$ ". This sixth " $\mathrm{C}$ " had already been discerned from our work within the Ujamaa Centre (West 2012), but remained a point of conversation among CEBI practitioners. We decided to include this sixth " $C$ " in our presentation: Contestation.

Here I will offer a bullet summary of each core value, followed by reflection. In each case the formulations are those of the Ujamaa Centre and its praxis of Contextual Bible Study (CBS) ${ }^{11}$ However, having said this, the formulations are also an attempt to capture the richness of our discussions in the multiple languages that were being used in the workshop.

\subsection{Community}

- Community is the beginning and goal of CBS;

- Community is the fabric of CBS;

- The communities of the organised poor, working-class, and other marginalised groups are the starting point and the primary "reality" of CBS;

- Community is also the primary "objective" of CBS, as CBS contributes towards the formation of redemptive communities, full of dignity, decent work, and abundant life for all.

Beginning with "community" is not accidental; CBS work as practised by both CEBI and the Ujamaa Centre "fore-grounds" or privileges particular

1 I will use the abbreviation "CBS" from now on; we have been asked by some of the communities we work with not to call what we do "Bible study", because they insist, what we do "is not what we do in church". 
sites of the organised marginalised. In terms of African biblical scholarship, community is the "subject" of our biblical interpretation (Ukpong 1995:5). In theological terms, CBS is incarnational, requiring real bodies as its social location.

\subsection{Criticality}

- CBS facilitates a "critical" (structured and systemic) analysis of all aspects of life;

- Specifically, CBS critically analyses the self, society, and the biblical text, using a range of structured and systematic questions;

- CBS constructs a critical dialogue between a critical reading of life (the first text) and a critical reading of the Bible (the second text).

Notions of "criticality" are central to but contested within various forms of contextual Bible reading. In the early understandings of contextual Bible reading within both CEBI and the Ujamaa Centre we worked with strong notions of criticality, in which critical consciousness was a resource socially engaged biblical scholar brought with them into a terrain of false consciousness among the poor and marginalised (Segundo 1985, West 1995, Dreher 2004 ). However, the praxis cycle of action and reflection has generated a deeper understanding of the fragility of ideological hegemony, as we have come to recognise that subaltern sectors are "less constrained at the level of thought and ideology, since they can in secluded settings speak with comparative safety, and more constrained at the level of political action and struggle, where the daily exercise of power sharply limits the options available to them" (Scott 1990:91, Schinelo 2009, West 2015a). So we now recognise the critical resources that are already present with organised communities of the poor and marginalised, among which the socially engaged biblical scholar brings the particular critical resources of biblical hermeneutics. In theological terms, CBS recognises the multiple gifts of the body of Christ as a whole.

\subsection{Collaboration}

- CBS is located within collaborative work and collaborative biblical interpretation among organised communities of the poor, workingclass, and marginalised, organic intellectuals from these sectors, and socially engaged ("converted") biblical scholars and theologians; 
- Collaboration begins with actual work in local struggles;

- Collaboration then goes on to include collaborative biblical interpretation and a collaborative "doing" of theology, moving from embodied theology to people's theology to prophetic theology.

"Struggle" was a key concept in South African Black Theology (Mosala 1989) and in South African Contextual Theology (Nolan 1988). And within both forms of South African theology there was a recognition of the necessity of collaboration among the different sectors that were engaged in the struggle against apartheid. While the poor, working-class, and other marginalised sectors were epistemologically privileged (Frostin 1988:6), each of the other sectors was recognised as having a contribution to make within organised forms of collaboration. And while both these forms of South African "liberation" theology had rich theological resources on which to draw in doing theology collaboratively, biblical studies battled to "allow" ordinary non-scholarly Bible readers to be interpret "with" scholarly readers (Okure 1993, West and Dube 1996). So collaborative biblical interpretation was a particular innovation within contextual Bible reading movements, including the Ujamaa Centre's CBS work.

\subsection{Change}

- CBS uses the Bible as a substantive and "subjective" companion to work for transformation;

- Transformation includes transformation of the self and society, including the church (and the religious terrain in general);

- The primary focus of transformation is the structural and systemic, and the primary terrain for transformation from the perspective of CBS is the ideo-theological.

Contextual Bible reading is not about understanding the Bible better. The Bible is read for change. The Bible as a site of struggle itself (see value 6) is wrestled with (or re-read) until it contributes to real, substantive, systemic change. The image of wrestling is taken from Genesis 32:24, where "struggling" with God leads to change in Jacob's relationships. Key to our understanding of change is that personal relationships are rooted in socio-economic systems. In theological terms, CBS struggles against the dominant individualist theologies of so much of South African theology. 
While recognising a place for individual change, individual change can only be considered "change" if it contributes to and is located within systemic change.

\subsection{Context}

CBS is embedded in the many "layers" of context, focussing on the systemicstructural "dimensions" of reality;

- CBS recognises that the self, society, and the biblical text are products of these layers or dimensions of context;

- Specifically, CBS offers resources to analyse the economic, cultural, political, and religious layers or dimensions of context;

- $\mathrm{CBS}$ recognises that context is dynamic, that it changes;

- CBS recognises that scripture is "already" present in contexts in which we work.

"Context" not only reiterates the significance of "community" (see above), but elaborates on the intersecting layers or dimensions of "reality". By making it clear that context is always religious, CBS avoids the false binary scripture/context. Theology never begins with scripture; it always begins with context, but a context that embodies particular interpretations of the Bible. And while contextual Bible reading movements, in both Brazil and South Africa, have given priority to economic dimensions of reality because it is the primary reality of "the poor" - there has been increasing recognition of the intersectionality of marginalisation, including class, race, gender, HIV status, disability, sexuality, etc. in our work. The work of the Circle of Concerned African Women Theologians has been a particular resource for CBS in this regard (Dube 2001).

\subsection{Contestation}

- CBS works with "struggle" as a key socio-theological concept;

- CBS recognises that struggle is a key characteristic of reality, and so CBS takes sides with the God of life against the idols of death;

- For CBS the primary "terrain" of struggle is the ideological and theological; 
- CBS recognises that the Bible is itself contested, including biblical "voices" or theologies that bring life and biblical "voices" or theologies that bring death;

- CBS "wrestles" with the biblical text to bring forth life.

The notion that the Bible is itself "a site of struggle", intrinsically both life-giving and death-dealing, is deeply rooted in South African Black Theology (Mofokeng 1988) and African Women's Theology (Nadar 2006), but has been an unfamiliar and uncomfortable notion within other forms of liberation theology (West 2013b). Yet again the reality of the poor and marginalised is that the Bible "lends itself" to idolatry (Hinkelammert 1986) and death, and so there is a greater willingness to grapple with this reality among liberation theologians. All theological frameworks bracket "bits" of the Bible that would destabilise the frame (Nürnberger 2002, 2004), yet the impression given is that a particular theological frame is what "the Bible says". CBS resists giving this impression, working overtly with the "partiality" (in both senses of the term) of both the Bible and each theological framework.

As indicated, the above formulations are mine, but have been carefully reflected on (in a range of languages) both by those of us at the Bogotá workshop and Ujamaa practitioners at a workshop in South Africa a week later. But they are, as is all of our reflection, part of the ongoing process of praxis, and so we will return to them regularly to reflect again in the light of our actual Contextual Bible Study practice. In what follows I offer an overview of the Ujamaa Centre's Contextual Bible Study practice, focussing on the collaborative interpretive processes that constitute CBS. As I do so, elements of each of the values outlined above will become evident.

\section{Collaborative work and interpretation}

Liberation theologies have forged a range of collaborative reading processes, but the focus here is on a form that has developed in South Africa from the mid-1980s. Contextual Bible Study, as it has come to be called, inhabits a collaborative nexus, captured by the six core values, between the epistemology of the poor and marginalised and the critical capacities of socially engaged biblical scholarship. 
For those socially engaged biblical scholars and theologians who hold to strong notions of hegemony, arguing that the poor and marginalised have been "colonised" by the dominant ideology and are trapped in "a culture of silence" (Frostin 1988:10, alluding to Freire 1985:72), the critical capacities of biblical scholarship are pivotal, providing "the theologian who wants to carry out a de-ideologizing task with valuable cognitive tools" (Segundo 1985:28, Nadar 2009, 2012). However, for others of us who hold to weak notions of ideological hegemony, the apparent silence of the poor and marginalised is not the silence of a consent to hegemony, but the silence of an embodied and lived but yet to be articulated "local" ideology (Scott 1990, West 2009).

Those of us socially engaged biblical scholars who work with a strong sense of the epistemological privilege of the poor and a weak sense of social hegemony recognise that the critical resources of biblical scholarship are brought alongside the array of critical capacities that have already been forged in the sequestered sites of organised communities of the poor and marginalised. These additional critical resources, the tools of the biblical studies discipline, derive their usefulness, in part, from their capacity to render the Bible "other". They slow down the interpretive process (Riches et al. 2010:41), facilitating re-reading, re-translation, and re-interpretation. Within the contours of Contextual Bible Study, alterity enables reappropriation for social transformation.

There are various ways of describing the Contextual Bible Study praxis (see the references already cited), but here I will focus on a series of interconnected "movements" that shape the collaborative reading process. While a little abstract at this point in the article, these movements will take on a fuller form in the final section.

The overarching movement is that of "See-Judge-Act", a process formed in the worker-priest movement in Europe in the 1930-40s (Cochrane 2001:76-77, West 1995:188-193). This movement begins within the organised formations of the poor and marginalised as they analyse ("See") their context, "from below". This analysis of "reality" is then brought into dialogue with the "prophetic" voices of the Bible, enabling "the God of life" to address ("Judge") the social reality. Through this dialogue with the Bible "the shape of the gospel" (Nolan 1988) is used to plan a series of actions 
("Act") that will bring about transformation of the social reality, so that all may have life, and have it abundantly.

Within this overarching movement there is another movement, from "community-consciousness" to "critical-consciousness" to "communityconsciousness". The "See" moment of social analysis generates a particular contextual concern that becomes the "theme" for the Bible study. The engagement with the Bible (the Judge component) begins with a community's "thematic" appropriation of the biblical text being used ("community-consciousness"), allowing every participant to share their particular understanding of the text. This moment not only makes it clear to the participants that the Bible study belongs to them, it also offers a reception history of that text's presence in a particular community. The Bible study then moves into a series of re-readings of the text, slowing down the process of interpretation, using the resources of socially engaged biblical scholarship ("critical-consciousness"). The particular sets of "critical" tools that constitute the trade of biblical scholarship are offered to the participants as additional resources with which to engage the biblical text. After a series of "critical-consciousness" questions, the Bible study moves back into "community-consciousness", as the participants appropriate (en-Act) the biblical text for the particular social project identified in the "See" moment.

With respect to the particular biblical "criticisms", there is another layer of movement. The movement begins within the "See" moment with an initial thematic "in-front-of-the-text" engagement with the text ("communityconsciousness"), bringing the generative contextual theme of the community workshop into dialogue with a particular biblical text. The interpretive process then slows down, entering the "critical-consciousness" moment via a literary engagement with the text. Though a form of "critical" engagement, the choice to focus begin critical engagement "on-the-text" offers an egalitarian entry point to "critical-consciousness", enabling all participants to engage with the detail of the text. In most cases, literary engagement leads "behind-the-text" to a socio-historical engagement with the text, as participants probe the world that produced the text, seeking for lines of connection between both the literary dimensions and the socio-historical dimensions of the text and their contextual realities, seeking lines of connection between contemporary communities of faith and struggle and "biblical" communities of faith and struggle. While 
these dimensions of the biblical text are the focus of these second and third moments, the process moves in the fourth moment back "in-frontof-the-text" (into "community-consciousness"), as the participants now appropriate this critically reconstituted text for their particular project of social transformation ("Act"). Together, as the examples that follow in the next section of the article illustrate, these concentric and intersecting movements constitute "the Contextual Bible Study process".

Facilitation (the term used by the Ujamaa Centre) and animation (the terms used by CEBI) processes are vital to the Contextual Bible Study, enabling both "group process" - the active participation of each participant - and the CBS process - the slow but steady procession through the three movements of CBS process (Hope and Timmel 1984). Part of the "conversion" of the socially engaged biblical scholar is becoming "re-schooled" as a facilitator, collaborating with other community-based facilitators so as to enable participatory transformation.

So Contextual Bible Study begins and ends under the control of a particular local community, who use the resources of the Contextual Bible Study, along with a range of other resources, to plan for and implement communitybased action. The socially engaged biblical scholar is already involved in the struggles of and work with particular communities for survival, liberation, life, so that the invitation (and motivation) to do Contextual Bible Study together comes from within this larger praxis. More than half a century of liberation hermeneutics has demonstrated the usefulness of the critical capacities of biblical scholarship to particular liberation struggles. More than twenty-five years of Contextual Bible Study has demonstrated the usefulness of this particular form of liberation hermeneutics to a range of struggles (both in South Africa and beyond), and it is from these that the examples in the final section of this article are drawn.

\section{Reading "with" local communities}

\section{Reading with Tamar}

Among the contextual realities of our collaborative praxis is the ongoing problem of violence against women and children. Colonialism, apartheid, and patriarchy have wreaked a vortex of havoc on African women and 
children. And while the Bible has voices that collude with and even inspire these destructive forces, the Ujamaa Centre has been working with 2 Samuel 13:1-22, an unfamiliar text in the liturgies and lectionaries of almost every Christian church, but a text that has demonstrated its capacity to empower women in their struggle against gender violence (West 2010a, West and Zondi-Mabizela 2004, West et al. 2004). The Contextual Bible Study (CBS) we use has the following shape:

2 Samuel 13:1-22 is read aloud, preferably dramatically. After the text has been read a series of questions follow:

1. Read 2 Samuel 13:1-22 together again in small groups. Share with each other what you think the text is about.

Each small group is then asked to report back to the larger group. Each and every response to question one is summarized on newsprint. After the report-back, the participants return to their small groups to discuss the following questions.

2. Who are the main characters in this story and what do we know about them?

3. What is the role of each of the male characters in the rape of Tamar?

4. What does Tamar say and what does Tamar do? Focus carefully on each element of what Tamar says and does.

When the small groups have finished their discussion, each group is invited to present a summary of their discussion. After this report-back the smaller groups reconvene and discuss the following questions.

5. Are there women like Tamar in your church and/or community? Tell their story.

6. What resources are there in your area for survivors of rape?

Once again, the small groups present their report-back to the plenary group. Creativity is particularly vital here, as often women find it difficult or are unable to articulate their responses. A drama or a drawing may be the only way in which some groups can report.

Finally, each small group comes together to formulate an action plan. 


\section{What will you now do in response to this Bible study?}

The action plan is either reported to the plenary or presented on newsprint for other participants to study after the Bible study.

Questions 2, 3, and 4 are "critical-consciousness" questions, slowing down the reading process by inviting a re-reading of the literary features of the text (and through them opening up space to explore behind-the-text). On either side of these questions that explore the alterity of the text are questions that embed the CBS in "community-consciousness".

More recently, we have constructed a variation on this CBS where we take up the challenge of the many women we have worked with to do work with "their men" around notions of masculinity. The advent of HIV and AIDS and the more recent roll-out of ARVs (antiretroviral drugs) has enabled men to take responsibility for their sexuality and their masculinity. The Ujamaa Centre has been invited into this space, where we have worked with local communities in a quest for redemptive forms of masculinity.

Among the constraints of working with this text with men has been Question 3, which frames each of the male characters as co-conspirators in the rape of Tamar. Yet such was the capacity of this text to enable men, as well as women, to talk about gender violence, that even as we used other biblical texts to work with notions of masculinity, we continued to reflect on this text in the context of this work. Two elements within the text itself prompted us to re-read the text and so to reconsider its potential as a resource with which engage notions of "redemptive" masculinity. The both occur in the first few verses:

${ }^{1}$ Some time passed. David's son Absalom had a beautiful sister whose name was Tamar; and David's son Amnon fell in love with her. ${ }^{2}$ Amnon was so tormented that he made himself ill because of his sister Tamar, for she was a virgin and it seemed impossible to Amnon to do anything to her (NRSV).

In the Tamar version of this Bible study (the one above), we worked with Phyllis Trible's pioneering "exegesis" of this text (Trible 1984), in which she considers the "exposition" of the narrative to be restricted to 13:1. In terms of plot, 13:2 is, for Trible, the start of the "complication". Though she does not use this form of plot analysis, a common way of analysing how plots 
"move", since Aristotle (Aristotle 1967:30), has been to see plot as having three fundamental movements: exposition, complication, resolution (Clines 1998:5). "Plots move", argues Jerome Walsh, "like an arc from a situation of (relative) stability, through a process of tension or destabilization, to a new situation of (relative) stability" (Walsh 2009:14). For Trible, verse 1 is the exposition (a situation of relative stability), and verse 2 is the beginning of the narrative tension. But what if 13:1-2 constitutes the "exposition"? What if the "complication" or tension only begins in 13:3? (West 2013a)

Our problem, as I have said, with using this text in our work with men was that it portrayed men as perpetrators, with each of the male characters playing some role in the rape of Tamar. Indeed, Question 3 invites such an analysis, and we did not want to relinquish this question, indicating as it does the systemic dimensions of patriarchy. But if verse 2 can be considered an aspect of the narrative's exposition, then it portrays an Amnon who is full of desire (love), but who does not act, precisely because, as Trible notes, "as a virgin, Tamar is protected property, inaccessible to males, including her brother" (Trible 1984:38). Amnon's state of heightened desire could be considered as a state of relative stability. Verses 1-2, we reflected, could form the exposition, introducing the family (13:1), and introducing the initial "stable" state of the relationship between Amnon and Tamar. On this exegesis of the text, Amnon is a normal male. Like most males he experiences sexual desire, but he does not (initially) act on this desire, because of a whole range of socio-cultural constraints. It is Jonadab who ushers in the complication (13:3), activating and plugging Amnon into the pathological patterns of patriarchal power. This insight, driven by a contextual demand to engage with masculinity, enabled us to re-read the detail of the text, offering us a way of working with this text with men.

The second element in the text was the translation of בהא (aheb). Most English translation use "love", and most of the other Bible translations we work with - for we always work in the languages and the translations of the local communities we work with - use their word for "love". However, our work with the Tamar CBS almost always led women to declare that a better translation would be "lust". And so, following their epistemological lead, we would translate the word as "lust". But what if, we later wondered as we re-read the text in the context of this work in the area of masculinity, the word really could be translated "love"? What if Amnon's feeling for Tamar, 
described in verse 1, were those of "love"? This might mean that there is a shift from verse 1 to verse 2, as Amnon allowed his "love" for Tamar to become distorted by the desire for power over her, so that "love" became something pathological. Here again was a potential resource to consider Amnon as more than a flat character. Perhaps the narrative implied some character development from verse 1 to verse 2 , which we could then use as a resource for reflection with contemporary men concerning masculinity. What are the personal-psychological and social-structural dimensions of a shift from "love" (verse 1) to (chalah) "obsessive illness" (verse 2), to הנע (anah) "violation/rape" (verse 14)?

These textual elements enabled us to construct another CBS using this same text. This Amnon CBS is part of our series on "redemptive masculinities". At the moment its form is somewhat flexible, but a relatively stable version of it is as follows:

1. Have you heard this text (2 Samuel 13:1-22) read publically ... on a Sunday? Share with each other if and when and where you have heard this text read.

2. Who are the main characters in this story and what do we know about them?

3. What is the role of each of the male characters in the rape of Tamar?

4. How would you characterize Amnon's masculinity in this text? Consider:

What prevents Amnon initially from acting on his love for Tamar (v2)?

What is it that changes Amnon's love (v1) to sickness/lust (v2), and then enables him to act on his sickness/lust (v4-6)?

How does he react to Tamar's arguments (v14)?

How does he behave after he has raped Tamar (v15-17)?

5. What kind of man does Tamar expect or hope Amnon to be? What kind of man could Amnon be according to Tamar? What kind of man does Tamar want? Consider: 
What does she say (v12-13, 16), and what do each of the things she says tell us about her understanding of what it means to be "a man"? What does she do (v19), and what do each of things she does tell us about her understanding of what it means to be "a man"?

6. What are the dominant forms of masculinity in our contexts (in various age groups), and what alternative forms of masculinity can we draw on from our cultural and religious traditions?

7. How can we raise the issue of masculinity in our various gender and age-groups?

These two Contextual Bible Studies inhabit the dialogical space between the epistemology of the women we work with, many of whom have experienced forms of abuse, and the detail of the text made apparent through the critical capacities of biblical scholarship. Both have the capacity to explore the personal-psychological and the social-structural dimensions of their respective areas of focus, namely gender violence and masculinity. Indeed, Question 5 in the redemptive masculinity version has the capacity to offer resources about what women want in "a man", as Tamar attempts to summon an alternative masculinity in Amnon.

This neglected biblical text, an unfamiliar text in the life of ordinary readers of the Bible, calls forth many moments of translation and/as interpretation as participants in the CBS process navigate this text's semantic fields of violence and love, some readily apparent to ordinary readers and some requiring access to the resources of biblical scholarship. ${ }^{22}$ Within the CBS processes, appropriation takes place either side of alterity.

These two examples illustrate the shape of CBS quite well, though they both have a much stronger and longer focus on the literary detail of the text than on the socio-historical detail. We always begin the movement into alterity with a literary focus, as this enables a more egalitarian entry point than beginning with socio-historical detail. All ordinary readers, even the illiterate (who hear the text), can follow the literary contours of

2 For example, there may be a play on words related to love and even eroticism in verses 6,8 , and 10 with reference to the (heart-shaped?) "cakes" Amnon asks Tamar to prepare for him; see (Hackett 1992:93) 
a text, particularly a narrative text. In this respect the work of the Ujamaa Centre is different from the earlier emphatic socio-historical starting point of much of the earlier work of biblical liberation hermeneutics in Latin America (Segundo 1985).

\section{Reading with the workers}

Focussing on the economic dimensions of text and context remains a distinctive feature of biblical liberation hermeneutics, even while other intersecting marginalisation have been incorporated around this primary focus. I use this next example not only to signal this economic emphasis, but to indicate a refusal to make an ideologically distinctive translation and/ as interpretation. What is foregrounded is the potential for contestation in both biblical text and social context.

The casualization of work has become a feature of the contemporary neoliberal capitalist global world order. South African reality is characterised by casual workers sitting on street corners of every city and town waiting for work. The haunting line in one of the parables of Jesus (Matthew 20:115/16) summoned us to re-read this text with these workers: "Why are you standing here idle all day?" (West and Zwane 2013) The history of reception of this text within biblical liberation hermeneutics, particularly within the Young Christian Workers (YCW) tradition, has been to read this text as an envisioning of a "socialist" world economic order, characterised by a reality in which the following saying, popularised by Karl Marx, would be true: "From each according to his ability, to each according to his needs" (Marx 1875).

However, in our work with the working-class sector, many of whom are casual workers, we had become disturbed by certain textual details.

${ }^{8}$ When evening came, the owner of the vineyard said to his manager, 'Call the laborers and give them their pay, beginning with the last and then going to the first. ' ${ }^{9}$ When those hired about five o'clock came, each of them received the usual daily wage. ${ }^{10}$ Now when the first came, they thought they would receive more; but each of them also received the usual daily wage. ${ }^{11}$ And when they received it, they grumbled against the landowner, ${ }^{12}$ saying, 'These last worked only one hour, and you have made them equal to us who 
have borne the burden of the day and the scorching heat.' ${ }^{13}$ But he replied to one of them, 'Friend, I am doing you no wrong; did you not agree with me for the usual daily wage? ${ }^{14}$ Take what belongs to you and go; I choose to give to this last the same as I give to you. ${ }^{15}$ Am I not allowed to do what I choose with what belongs to me? Or are you envious because I am generous?' (Matthew 20:8-15 NRSV)

Casual workers were disturbed that "the owner", having hired the workers, now sends his "manager" to pay them. Why this change? they asked. They were particularly distressed by the strategy of the manager, isolating the representative of the workers (verse 13), singling him out, refusing to engage with the concerns he brought to the manager on behalf of the other workers who had been working the whole day, and then dismissing him. This "divide and rule" strategy was familiar to them, whenever they raised concerns with those who hired them. But what was most troubling to them was the assertion of the manager that he could act in an arbitrary manner because he had the power to do so (verse 15a).

Such concerns required that we socially engaged biblical scholars re-read this text from this reality. When we did we found socio-historical resources that resonated with what workers had discerned in the literary detail. We were drawn to William Herzog's reading of this parable, identifying with his notion of Jesus as "pedagogue of the oppressed", and his location of this parable within the realities of the conflictual interface between peasant subsistence farmers and the exploitative and extractive economies of citybased elites (Herzog 1994). Read from such a perspective the contours of the parable are clearer. The owner of the vineyard is likely an absentee landowner, a member of the economic urban elite, employing a manager to handle the daily affairs of the vineyard, and engaged in a form of agriculture that produced "a crop that can be converted into a luxury item (wine), monetized, and exported” (Herzog 1994:85).

Unable to calculate how many labourers he will need, such is the extent of his land holdings, the owner must make a number of trips to the agora to hire workers. Regular assessment of the number of workers he needs also enables the landowner to keep his workers to the minimum necessary to harvest the crop within the designated time period. Furthermore, by hiring small numbers of labourers during the day, the landowner 
exercises his "unilateral power", negotiating only with those hired at the beginning of the day for the minimum daily wage (Herzog 1994:89-90), but leaving the wage for those hired later in the day indeterminate (verse 4,7) (Herzog 1994:86). For in a context of chronic systemic unemployment and underemployment the day-labourer is in no position to insist on a just wage, having to accept "a malnutrition wage" (Herzog 1994:2). "Far from being generous", as he claims "the householder is taking advantage of an unemployed work force to meet his harvesting needs by offering them work without a wage agreement" (Herzog 1994:86).

By telling a story in which the landowner is actively involved in the economic process, Jesus foregrounds the socio-economic contestation of his time, making the usually invisible absentee landlord visible and so setting up a direct encounter between "the elites and the expendables" (Herzog 1994:87). The arbitrary economic power of the landowner is evident in the payment process. His power is signalled in the delegation of his manager to make the payments, but is fully manifest in his deliberate flaunting of protocol by refusing to pay the first-hired labourers first; by making the first-hired wait until last he flaunts his power and shames them. The dignity of those who have worked all day demands a response, and so they risk a protest (verse 11-12), speaking back to power, invoking the principle of equal pay for equal work (Herzog 1994:91-92). Singling out their spokesperson (verse 13a), the landowner condescendingly reminds the resisting workers of their contractual agreement, knowing fully well that the day-labourers were never in a position to negotiate anything other than the minimum wage, and then goes on to dismiss their complaints, reiterating his right to do what he pleases with his power (verse 14), and concluding by blasphemously asserting that the land, which has been systemically coerced from the very peasant farmers who are now day-labourers, belongs to him (verse 15) (Herzog 1994:92-94). On this reading the systemic economic violence behind this text is palpable (Herzog 1994:94).

Given this analysis, we have been tempted to offer an ideologically loaded

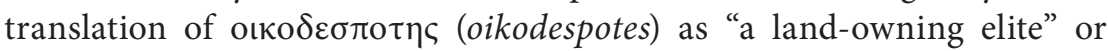
even "a white land owner" and $\varepsilon \pi 1 \tau \rho \circ$ о designations that would resonate immediately with South Africa's casual workers. Such translations would remove any ambiguity as to whether this text was advocating a form of "socialism" or critiquing a form of 
"capitalism". Instead, we have chosen to go with the more "neutral" translations of most versions, translations like "landowner" and "manager" respectively. We have then offered two options for reading this parable. The Bible study begins (in this version) with a series of common questions and then divides into two separate sets of questions, before concluding with a return to common questions.

1. A poster picture of workers sitting at a street corner is used as an introductory exercise. Participants are asked: What do you see in this picture?

2. Matthew 20:1-15 is then read aloud.

Participants are asked: What is the text about?

After general discussion of these two questions, participants are divided into small groups for the remaining questions.

3. Who are the characters in this text and what is their relationship to each other?

After each small group has given its report to Question 3, the facilitator gives the following input:

In the time of Jesus many peasant farmers had been forced off their land by becoming indebted to wealthy city-based elites from whom they had taken loans in times of economic hardship. Those who lost their land became day-labourers. So there are two very different ways of reading this text:

A. This text can be read as presenting the egalitarian "socialist" vision of Jesus and the early Jesus movement (Acts 4:32-35), where there is work for all and decent wages for all. As Karl Marx said, "From each according to their ability to each according to their needs". From this perspective, we might read the parable as a utopian vision of a "socialist" society.

B. This text can also be read as a critique by Jesus of the arbitrary and discriminating practices of "capitalist" landowners, who hire when they like and pay what they like. From this perspective, the workers do not receive a just wage, they receive the exploitative minimum daily rate, and no more. 
After this input the small groups are divided into two sets, set A and set B. Each set takes up their respective questions:

\begin{tabular}{|c|c|}
\hline $\begin{array}{l}\text { A: a "socialist" interpretation } \\
\text { 4. If the landowner represents the } \\
\text { egalitarian communal vision of Jesus } \\
\text { and the kingdom of God, what is the } \\
\text { relationship between the landowner and } \\
\text { the workers in this text? Focus on the } \\
\text { detail of the text. } \\
\text { 5. What aspects of this parable are } \\
\text { relevant to the current context of } \\
\text { unemployment? }\end{array}$ & $\begin{array}{l}\text { B: a "capitalist" interpretation } \\
\text { 4. If the landowner represents the } \\
\text { exploitative ruling economic elite in the } \\
\text { first century, what is the relationship } \\
\text { between the landowner and the workers in } \\
\text { this text? Focus on the detail of the text. } \\
\text { 5. What aspects of this parable are relevant } \\
\text { to the current context of unemployment? }\end{array}$ \\
\hline
\end{tabular}

After each set of small groups has reported on these questions, the participants work together on the following questions:

6. Which of these interpretations do you think is Matthew's? Do you think Matthew represents what Jesus might have be saying by telling this parable?)

7. What do each of these two different readings say to our context?

8. What actions will we take in response to these readings?

Resisting a particular ideological option in this case creates the opportunity for a different kind of pedagogical experience, within which participants grapple with the notion that "scripture" does not have one voice. Contending voices can be discerned, whether using literary or sociohistorical (redactional) resources. Question 6 deals directly with different "redactional" perspectives, but may deflect some groups from moving into community consciousness in Questions 7 and 8. The recognition that the Bible is itself a site of struggle has become increasingly important in the work of the Ujamaa Centre. Because our work destabilises dominant readings of the Bible, we have to guard against giving the impression that "the Bible" is unambiguously about liberation. 


\section{Conclusion}

Contextual Bible Study constructs a safe sequestered site in which communities of the poor and marginalised can be both translators and interpreters, both of their contexts and of their Bibles. Contextual Bible Study also offers access to the detail of the biblical text. This alterity enables liberatory appropriation in African contexts, for "other" detail unsettles the singular and certain "message" of the Bible. Claims to a contextually transcendent message serves Africa's ruling elites, forestalling the contending voices that cry out for structural change (West 2010b).

Contextual Bible Study as a particular form of liberation hermeneutics occupies a tensive interpretive space in which we risk a decisive ideotheological framing which enables a collaborative discerning of critical textual detail that is both "true" to the text's otherness but also potentially "useful" for particular local contextual struggles. Contextual Bible Study occupies a collaborative nexus between the epistemology of the poor and marginalised and the critical capacities of socially engaged biblical scholarship. The socially engaged biblical scholar who inhabits this collaborative nexus is both accountable to the particular communities of this collaborative praxis and responsible to the disciplinary detail of biblical scholarship.

This nexus then is characterised by a dialectical relationship between alterity and appropriation, with appropriation seeking "exegesis" and "exegesis" seeking appropriation. The alterity which the detail of biblical scholarship offers to organised poor and marginalised "readers" of the Bible is, this article argues, a significant resource in appropriations of the Bible for social transformation within a liberation paradigm. And the appropriations of poor and marginalised "readers" generate their own forms of alterity, summoning the socially engaged biblical scholar to return to the discipline of biblical scholarship in order to discern other detail that might be potentially useful. Biblical liberation hermeneutics as it is construed within the processes of Contextual Bible Study recognises that the distinctive detail of a biblical text (its alterity) and a particular community's appropriation of that text are always partial, in both senses of the term: they are ideo-theologically constituted and incomplete. 
As the two examples have indicated, Contextual Bible Study is not just technique, it is embedded and embodied in a set of core values. Its value derives from these values.

\section{Bibliography}

Aristotle. 1967. Poetics. Translated by Gerald F. Else. Ann Arbor: The University of Michigan Press.

Clines, David JA 1998. "Reading Esther from left to right: contemporary strategies for reading a biblical text." In On the way to the postmodern: Old Testament essays, 1967-1998, edited by David J. A. Clines, 3-22. Sheffield: Sheffield Academic Press.

Cochrane, James R 2001. "Questioning contextual theology.” In Towards an agenda for contextual theology: essays in honour of Albert Nolan, edited by McGlory T Speckman and Larry T Kaufmann, 67-86. Pietermaritzburg: Cluster Publications.

De Wit, Hans 2004. "Intercultural hermeneutics." In Through the eyes of another: intercultural reading of the Bible, edited by Hans de Wit, Louis Jonker, Marleen Kool and Daniel Schipani, 477-492. Elkhard, IN: Institute of Mennonite Studies and Vrije Universiteit.

De Wit, Hans 2012. Empirical hermeneutics, interculturality, and Holy Scripture. Elkhart, IN: Institute of Mennonite Studies.

Dreher, Carlos A 2004. The walk to Emmaus. São Leopoldo: Centro de Estudos Bíblicos.

Dube, Musa W 2001. Other ways of reading: African women and the Bible. Atlanta: Society of Biblical Literature.

Freire, Paulo 1985. The politics of education: culture, power, and liberation. Westport, CT: Greenwood Publishing Group.

Frostin, Per 1988. Liberation theology in Tanzania and South Africa: a First World interpretation. Lund: Lund University Press.

Hackett, Jo Ann 1992. “1 and 2 Samuel." In The women's Bible commentary, edited by Carol A Newsom and Sharon H Ringe, 85-95. London and Louisville, Kentucky: SPCK and Westminster/John Knox Press. 
Herzog, William R 1994. Parables as subversive speech: Jesus as pedagogue of the oppressed. Louisville: Westminister/John Knox.

Hinkelammert, Franz J 1986. The ideological weapons of death: a theological critique of capitalism. Maryknoll: Orbis.

Hope, Anne, and Timmel, Sally 1984. Training for transformation: a handbook for community workers. 4 vols. Vol. Book 1. Gweru: Mambo Press.

Marx, Karl 1875. “Critique of the Gotha Program.” In: Marx \& Engels [Online] http://marxistsfr.org/archive/marx/works/1875/gotha/index.htm.

Mesters, C 1984. "The use of the Bible in Christian communities of the common people." In The Bible and liberation: political and social hermeneutics, edited by Norman K Gottwald and Richard A Horsley, 3-16. Maryknoll, NY: Orbis Books.

Mesters, Carlos 1989. Defenseless flower: a new reading of the Bible. Translated by Francis McDonagh. Maryknoll, NY: Orbis Books.

Mesters, Carlos nd. God's project. Cape Town: The Theology Exchange Programme.

Mofokeng, Takatso 1988. "Black Christians, the Bible and liberation." Journal of Black Theology no. 2:34-42.

Mosala, Itumeleng J 1989. Biblical hermeneutics and black theology in South Africa. Grand Rapids: Eerdmans.

Nadar, Sarojini 2006. “'Barak God and die!': Women, HIV, and a theology of suffering." In Voices from the margin: interpreting the Bible in the Third World, edited by RS Sugirtharajah, 189-203. Maryknoll: Orbis.

Nadar, Sarojini 2009. “Beyond the 'ordinary reader' and the 'invisible intellectual': shifting Contextual Bible Study from liberation discourse to liberation pedagogy." Old Testament Essays no. 22 (2):384-403.

Nadar, Sarojini 2012. “'Hermeneutics of transformation?' A critical exploration of the model of social engagement between biblical scholars and faith communities." In Postcolonial perspectives in African biblical interpretations, edited by Musa W Dube, Andrew M Mbuvi and Dora Mbuwayesango, 389-406. Atlanta: Society of Biblical Literature. 
Nolan, Albert 1988. God in South Africa: the challenge of the gospel. Cape Town: David Philip.

Nürnberger, Klaus 2002. Theology of the Biblical witness: an evolutionary approach. Münster: Lit.

Nürnberger, Klaus 2004. Biblical theology in outline: the vitality of the word of God. Pietermaritzburg; Pretoria: Cluster Pub; CB Powell Bible Centre.

Okure, Teresa 1993. "Feminist interpretation in Africa." In Searching the Scriptures: a feminist introduction, edited by Elisabeth Schussler Fiorenza, 76-85. New York: Crossroads.

Riches, John, Helen Ball, Roy Henderson, Craig Lancaster, Leslie Milton, and Maureen Russell 2010. What is Contextual Bible Study? A practical guide with group studies for Advent and Lent. London: SPCK.

Schinelo, Edmilson 2009. The Bible and popular education; encounters of solidarity and dialogue. São Leopoldo: CEBI.

Scott, James C 1990. Domination and the arts of resistance: hidden transcripts. New Haven and London: Yale University Press.

Segundo, Juan Luis 1985. "The shift within Latin American theology." Journal of Theology for Southern Africa no. 52:17-29.

Trible, Phyllis 1984. Texts of terror: literary-feminist readings of biblical narratives. Philadelphia: Fortress.

Ukpong, Justin S 1995. "Rereading the Bible with African eyes." Journal of Theology for Southern Africa no. 91:3-14.

Walsh, Jerome T 2009. Old Testament narrative: a guide to interpretation. Louisville: Westminster John Knox Press.

West, Gerald O 1991. Biblical hermeneutics of liberation: modes of reading the Bible in the South African context. Pietermaritzburg: Cluster Publications.

West, Gerald O 1993. Contextual Bible study. Pietermaritzburg: Cluster Publications.

West, Gerald O 1995. Biblical hermeneutics of liberation: modes of reading the Bible in the South African context. Second Edition (ed). Maryknoll and Pietermaritzburg: Orbis Books and Cluster Publications. 
West, Gerald O 2009. “The not so silent citizen: hearing embodied theology in the context of HIV and AIDS in South Africa." In Heterotopic citizen: new research on religious work for the disadvantaged, edited by Trygve Wyller, 23-42. Göttingen: Vandenhoeck \& Ruprecht.

West, Gerald O 2010a. "The contribution of Tamar's story to the construction of alternative African masculinities." In Bodies, embodiment, and theology of the Hebrew Bible, edited by Tamar Kamionkowski and Kim Wonil, 184-200. London: T\&T Clark.

West, Gerald O 2010b. "Unstructural analysis of the Bible reinforcing unstructural analysis of African contexts in (South) Africa?" Old Testament Essays no 23(3):861-888.

West, Gerald O 2011a. "Do two walk together? Walking with the other through Contextual Bible Study." Anglican Theological Review no. 93(3):431-449.

West, Gerald O 2011b. "Newsprint theology: Bible in the context of HIV and AIDS." In Out of place: doing theology on the crosscultural brink, edited by Jione Havea and Clive Pearson, 161-186. London: Equinox Publishing.

West, Gerald O 2012. "Tracing the 'kairos' trajectory from South Africa (1985) to Palestine (2009): discerning continuities and differences." Journal of Theology for Southern Africa no. 143:4-22.

West, Gerald O. 2013a. "Deploying the literary detail of a biblical text (2 Samuel 13:1-22) in search of redemptive masculinities." In Interested readers: essays on the Hebrew Bible in honor of David JA Clines, edited by James K Aitken, Jeremy MS Clines and Christl M Maier, 297-312. Atlanta: Society of Biblical Literature.

West, Gerald O 2013b. "Liberation hermeneutics." In The Oxford encyclopedia of biblical interpretation, edited by Steven L McKenzie, 507-515. Oxford: Oxford University Press.

West, Gerald O 2015a. "Africa's liberation theologies: an historicalhermeneutical analysis." In The changing world religion map: sacred places, identities, practices and politics, edited by Stanley D. Brunn, 1971-1985. Dordrecht, Heidelberg, New York, London: Springer. 
West, Gerald O 2015b. “Locating 'Contextual Bible Study’ and intercultural biblical hermeneutics within biblical liberation hermeneutics". In New perspectives on Intercultural reading of the Bible: hermeneutical explorations in honor of Hans de Wit, edited by Daniel S Schipani, Martien Brinkman and Hans Snoek, 107-135. Elkhart: Institute of Mennonite Studies.

West, Gerald O, and Musa, W Dube. 1996. Reading with: African overtures, Semeia. Atlanta: Society of Biblical Literature.

West, Gerald O \& Zondi-Mabizela, Phumzile 2004. “The Bible story that became a campaign: the Tamar Campaign in South Africa (and beyond)." Ministerial Formation no. 103:4-12.

West, Gerald O, Zondi-Mabizela, Phumzile; Maluleke, Martin; Khumalo, Happiness; Matsepe, P Smadz and Naidoo, Mirolyn 2004. "Rape in the house of David: the biblical story of Tamar as a resource for transformation." Agenda no. 61:36-41.

West, Gerald O and Zwane, Sithembiso 2013. "Why are you sitting there?" Reading Matthew 20:1-16 in the context of casual workers in Pietermaritzburg, South Africa." In Matthew: texts@contexts, edited by Nicole Duran Wilkinson and James Grimshaw, 175-188. Minneapolis: Fortress Press.

Wittenberg, Gunther H 2007. Resistance theology in the Old Testament: collected essays. Pietermaritzburg: Cluster Publications. 